\title{
Crustal structure of the southeastern margin of the Ordos Block
}

\author{
LU YiFeng*, XU MingJie*, WANG LiangShu, MI Ning, LI Hua \& YU DaYong \\ School of Earth Sciences and Engineering, Nanjing University, Nanjing 210093, China
}

Received July 29, 2011; accepted September 20, 2011

\begin{abstract}
We use a profile made up of teleseismic receiver functions to study the crustal thickness and structure of the southeastern margin of the Ordos Block. The Mohorovičić discontinuity(Moho) has been identified beneath all stations. Its depth gradually decreases towards the southeast, from about $43 \mathrm{~km}$ in the Ordos Block to $\sim 30 \mathrm{~km}$ near the northern margin of the Qinling Orogen. Our results show clear lateral variations in the structure of the crust and the features of the Moho. Accordingly, the study region can be divided into four parts: (1) Beneath the Ordos Block, the Moho is visible and flat at a depth of $\sim 40 \mathrm{~km}$. The crustal structure is best characterized by stable cratonic crust. (2) In the Weihe-Shanxi Graben, the Moho is uplifted by about $3 \mathrm{~km}$, which may be the result of upwelling of upper mantle materials. (3) Under the Xionger-Funiu Mountains, the Moho is flat at a depth between 36 and $33 \mathrm{~km}$, but becomes shallower towards the southeast. (4) In the Hehuai Basin, adjacent to the northern margin of the Qinling Orogen, the Moho shows strong lateral variations with a mean depth of $\sim 31 \mathrm{~km}$. The crustal structure here is complex, which may indicate a complicated tectonic environment. Additionally, the Moho is clearly interrupted at two locations (beneath stations st11 and st18) near major tectonic boundaries. These results suggest that the structure of the deep crust along the southeastern margin of the Ordos Block has great lateral variability, which strongly affects the complex geological features on the surface. Furthermore, these results can help us understand the interrelationships of different parts of the southeastern margin of the Ordos Block.
\end{abstract}

receiver function, crustal structure, Moho, $H-\kappa$ stacking, CCP migration

Citation: $\quad$ Lu Y F, Xu M J, Wang L S, et al. Crustal structure of the southeastern margin of the Ordos Block. Chinese Sci Bull, 2011, 56: 3854-3859, doi: $10.1007 / \mathrm{s} 11434-011-4847-7$

The North China Block (NCB) was formed by the collision of the Eastern Block (EB) and the Western Block (WB) in the Precambrian $(\sim 1.8 \mathrm{Ga})$ [1]. From the Late Neopaleozoic to Early Mesozoic, the South China Block (SCB) moved northward and collided with the $\mathrm{NCB}$, and the Qingling Orogen was formed [2]. Meanwhile, the WNW-ESE striking Xionger-Funiu Mountains were formed in the southern NCB because of increasing N-S compression [3]. In the Cenozoic Era, many rift basins were formed around the Ordos Block due to widespread extension, caused by the Indo-Asian collision and the subduction of the Pacific Plate [4]. Also, a series of E-W and WNW-ESE striking left-lateral strike-slip faults developed along the southern margin of the NCB due to the uplift and eastward extrusion of the Tibetan Plateau [5,6]. Therefore, since the NCB

*Corresponding authors (email: luyifeng1985@sina.com; goxu@nju.edu.cn) formed, the southeastern margin of the Ordos Block has been affected by several tectonic events and its structure has become complex. This study region (Figure 1(a)) is located in a transitional zone between the contractional regime of western China and the extensional setting of eastern China.

The details of the crustal structure can provide important constraints on geodynamical studies of the area. In recent years, much research has been undertaken to evaluate the crustal structure of the NCB [7-11]. For example, receiver functions have been widely applied to investigate the crustal and upper mantle structure in a variety of regions [12-14]. In order to better understand the geodynamics of the southeastern margin of the Ordos Block, we calculate the receiver functions using teleseismic data recorded by a portable temporary broadband seismograph array. The results add constraints to our knowledge of the crustal thickness and the Moho discontinuity. 


\section{Data and methods}

From August 2008 to June 2010, a portable broadband seismograph array with 22 stations was deployed in the southeastern margin of the Ordos Block (Figure 1(c)). Each seismic station consists of a seismometer (CMG-40T) and a digital sampler (Refteck II) with a sampling rate of $40 \mathrm{~Hz}$. Using earthquakes with magnitudes greater than 5.5 located within an epicentral distance of $30^{\circ}, 80^{\circ}$, we picked 453 well-recorded earthquakes (Figure 1(b)). We cut $160 \mathrm{~s}$ records (10 s before and $150 \mathrm{~s}$ after the direct $\mathrm{P}$ wave) from every event. Then, we rotated the N-S and E-W waveforms into radial and transverse components. We calculated P-to-S receiver functions using time-domain maximum entropy deconvolution for each station [15]. The Gaussian coefficient and water level are 2.5 and 0.01, respectively. Finally, we obtained 1145 receiver functions. Figure 2 shows an example of receiver functions recorded at Station st22. The primary P-to-S conversion phases are clearly shown in the receiver functions.

In order to reduce incoherent noise efficiently and identify weak signals, we used a nonlinear stacking technique called the phase-weighted stack (PWS) to stack the radial receiver functions for each station [16]. Before the PWS, we applied a distance moveout correction for Ps phases [17]. We chose $65^{\circ}$ as the fixed distance. The crustal mean $\mathrm{P}$-wave velocity and $V \mathrm{p} / V \mathrm{~s}$ ratio used to compute the distance moveout corrections are $6.3 \mathrm{~km} / \mathrm{s}$ and 1.73 , respec- tively. The stacked results are plotted along Profile AB in Figure 3.

We further used the $H-\kappa$ stacking method [18] to estimate the average thickness $(H)$ and $V \mathrm{p} / V \mathrm{~s}$ ratio $(\kappa)$ of the crust beneath each station (Table 1). To balance the contributions from different phases, the weights for Ps, PpPs and PpSs+PsPs are chosen as 0.7, 0.2 and 0.1, respectively. The mean P-wave velocity of the crust was chosen to be 6.3 $\mathrm{km} / \mathrm{s}$. We show two examples of the $H-\kappa$ stacking results obtained from one station located in the Ordos Block (st01, Figure 4(a)) and another one from the Xionger-Funiu Mountains (st14, Figure 4(b)). The results are listed in Table 1 . In Table 1 , we also show standard variances of $H$ and $\kappa$. Then we plotted a depth and $\kappa$ section along Profile AB in Figure 5, without the results of Station st09, st11 and st18.

We migrated the receiver functions into the space domain to image seismic discontinuities by using the Common Conversion Point (CCP) stacking technique [19-21]. We obtain the CCP migration image of receiver functions along the Profile AB (Figure 6). For this study, we choose the IASP91 model as the initial crust velocity model. The horizontal grid spacing is $10 \mathrm{~km}$, and the vertical grid spacing is $2 \mathrm{~km}$.

\section{Results}

Most of the stations readily show Moho P,S converted (Ps)
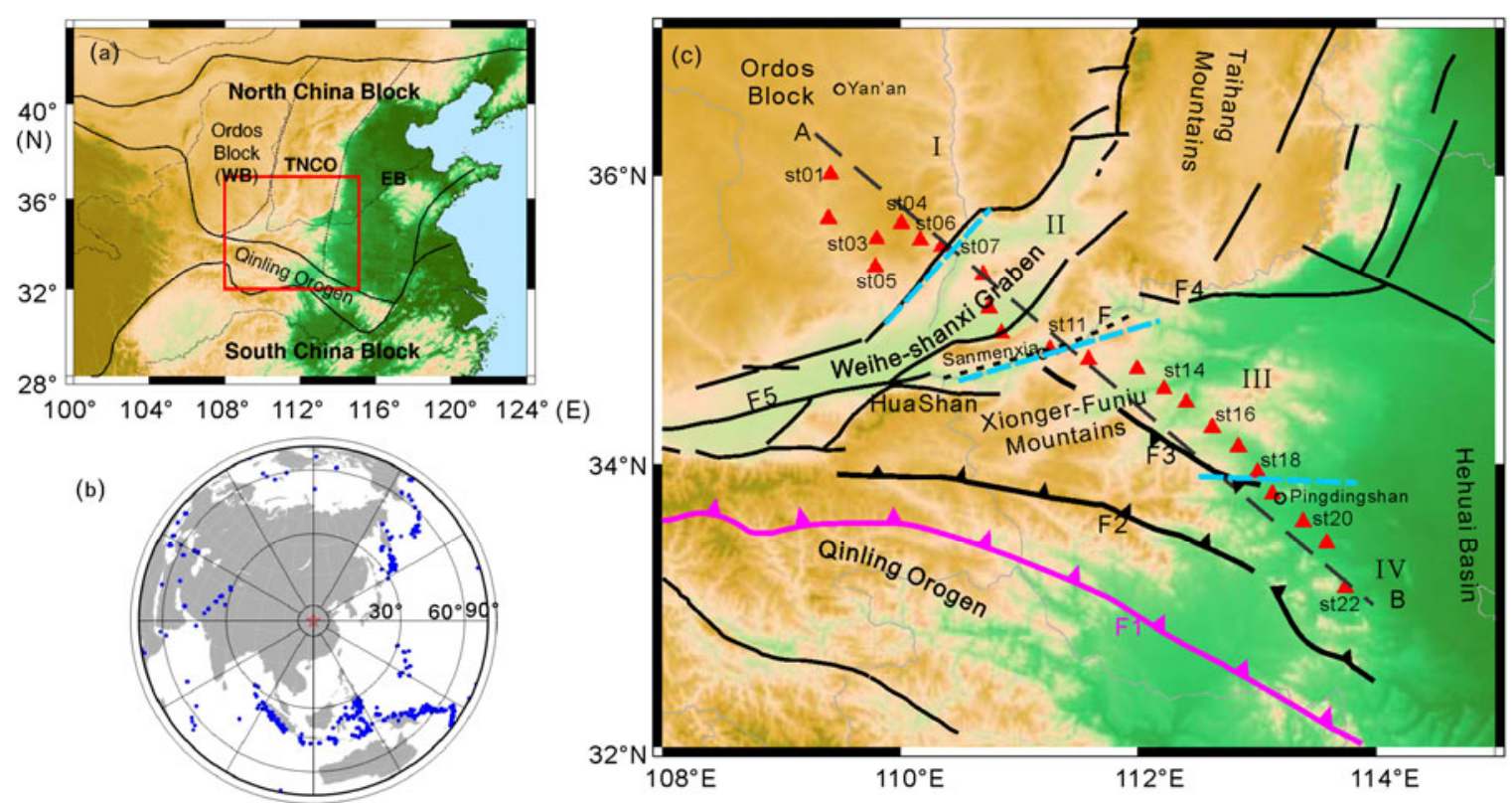

Figure 1 (a) Map of the tectonic setting in the southeastern margin of the Ordos Block. The study region is shown in the red square. (b) The distribution of teleseismic events used. The blue dots denote earthquakes with $M \geqslant 5.5$ between August 2008 and June 2010. The red star denotes the center of the seismic array. (c) The red triangles denote stations. The gray dashed line $\mathrm{AB}$ is the location of the observation profile with end-points $\mathrm{A}\left(36.3^{\circ} \mathrm{N}, 109.3^{\circ} \mathrm{E}\right)$ and $\mathrm{B}$ $\left(33.0^{\circ} \mathrm{N}, 114.0^{\circ} \mathrm{E}\right)$. The black lines denote faults. F1: Mianlve-Yvexi Suture Line. F2: Luanchuan-Gushi Fault. F3: Sanmenxia-Lushan Fault. F4: the southern marginal fault zone of the Taihangshan Mountains. F5: Weihe Fault. The black dashed line F denotes a possible fault that may be the extension of F4 or F5. The blue dashed lines are boundaries between different tectonic regions of the Profile AB. Tectonic regions are: I, Ordos Block; II, Weihe-Shanxi Graben; III, Xionger-Funiu Mountains; IV, Hehuai Basin, adjacent to the northern margin of the Qinling Orogen. 


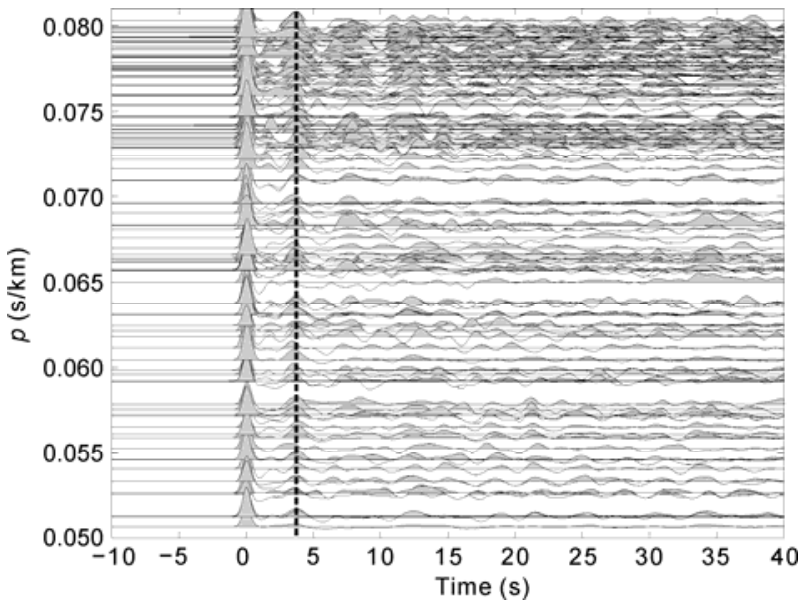

Figure 2 An example of the receiver functions recorded at Station st22 located in the Hehuai Basin. Dashed line indicates the arrival times of the primary P-to-S converted phase.

phases (Figure 3). The most prominent feature in the study area is that the Moho becomes shallower to the southeast, which is in agreement with the variations observed in Bouguer gravity anomalies here (Figure 6). The depth of the Moho decreases southeastward, from about $43 \mathrm{~km}$ in the Ordos block to $\sim 30 \mathrm{~km}$ near the northern margin of the Qinling Orogen.

In the Ordos Block, Ps phases can be identified clearly at around $5 \mathrm{~s}$. The crust is about $40 \mathrm{~km}$ thick and the Moho discontinuity is flat with a depth of $\sim 40 \mathrm{~km}$. Its depth decreases gradually toward the southeast. The estimated $V \mathrm{p} / V \mathrm{~s}$ ratios are around 1.74, varying from 1.69 to 1.78 .

Beneath the Weihe-Shanxi Graben, the Ps phases are not generally clear at first due to the interference of multiple reflections from sedimentary deposits. However, after being stacked through the PWS method, some of the multiple re- flections from sedimentary deposits can be reduced in amplitude. The depth of the Moho here is about $35 \mathrm{~km}$, which is $\sim 3 \mathrm{~km}$ shallower than in adjacent regions. The estimated $V \mathrm{p} / V \mathrm{~s}$ ratios are relatively high at $>1.79$.

In the Xionger-Funiu Mountains, the Ps phases can be observed clearly at $\sim 4 \mathrm{~s}$. The Moho here is continuous at a depth between 36 and $33 \mathrm{~km}$, which gradually decreases southeastward. The estimated $V \mathrm{p} / V \mathrm{~s}$ ratios are around 1.73 .

In the Hehuai Basin, adjacent to the northern margin of the Qinling Orogen, the Ps phases are clear but not continuous. The crust is relatively thin at about $31 \mathrm{~km}$, and the Moho topography here is complex. The estimated $V \mathrm{p} / V \mathrm{~s}$ ratios vary greatly from 1.65 to 1.88 .

The Ps phases of two stations (st11 and st18) are identified at nearly $6 \mathrm{~s}$. Also, the Moho is clearly interrupted near these two stations (Figure 6).

\section{Discussion and conclusions}

Our results suggest that the crustal structure of the southeastern margin of the Ordos Block is characterized by strong lateral variations, as indicated by the change of crustal thickness and Moho topography (Figures 5 and 6). Accordingly, the study area can be divided into four parts: (I) the Ordos Block, (II) the Weihe-Shanxi Graben, (III) the Xionger-Funiu Mountains and (IV) the Hehuai Basin (Figure 1(c)).

The Moho discontinuity in the Ordos Block is generally flat at a depth of $\sim 40 \mathrm{~km}$, which gradually decreases towards the southeast. Pan et al. obtained similar results in this area using receiver function data [22]. Our results are also consistent with those obtained through artificial earthquake [23] and gravity data [24]. Since the Precambrian, deformation in the Ordos Block has been weak [4],

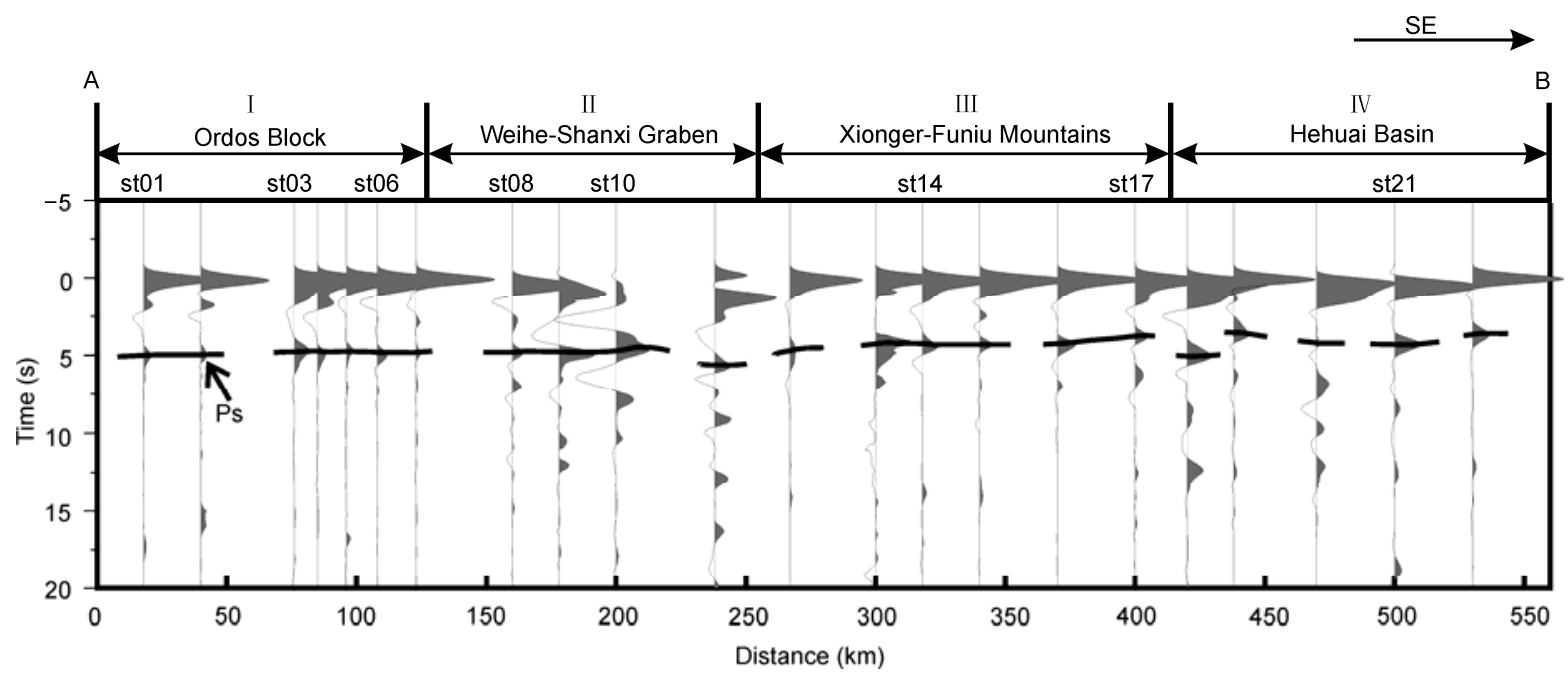

Figure 3 The PWS results of radial receiver functions for all stations. The results are aligned by the stations' locations projected on to the Profile AB. The location of the Profile AB is shown in Figure 1. The solid black line indicates delay times of Ps phases for every station. Tectonic regions of the Profile AB are shown at the top. 
Table 1 The crustal thickness $(H)$ and average $V \mathrm{p} / V \mathrm{~s}$ ratio $(\kappa)$ at 22 stations

\begin{tabular}{|c|c|c|c|c|}
\hline Station & $H(\mathrm{~km})$ & $\kappa$ & RFs No. & Tectonic zone \\
\hline st01 & $43.5 \pm 0.9$ & $1.69 \pm 0.01$ & 31 & \multirow{6}{*}{ I Ordos Block } \\
\hline st02 & $40.6 \pm 0.9$ & $1.73 \pm 0.01$ & 22 & \\
\hline st03 & $38.8 \pm 0.9$ & $1.73 \pm 0.01$ & 85 & \\
\hline st04 & $38.2 \pm 0.8$ & $1.78 \pm 0.01$ & 111 & \\
\hline st05 & $39.8 \pm 0.6$ & $1.72 \pm 0.01$ & 18 & \\
\hline st06 & $37.8 \pm 0.8$ & $1.78 \pm 0.01$ & 139 & \\
\hline st08 & $36.0 \pm 0.8$ & $1.79 \pm 0.01$ & 56 & \multirow{4}{*}{ II Weihe-Shanxi Graben } \\
\hline $\mathrm{st} 9^{\mathrm{a})}$ & $\times$ & $\times$ & $x$ & \\
\hline st10 & $33.4 \pm 1.2$ & $1.85 \pm 0.01$ & 61 & \\
\hline $\mathrm{st} 11^{\mathrm{b})}$ & $38.4 \pm 0.8$ & $1.89 \pm 0.01$ & 77 & \\
\hline st12 & $32.8 \pm 1.1$ & $1.84 \pm 0.02$ & 70 & \multirow{5}{*}{ III Xionger-Funiu Mountains } \\
\hline st13 & $35.6 \pm 0.8$ & $1.73 \pm 0.01$ & 10 & \\
\hline st14 & $34.6 \pm 0.8$ & $1.76 \pm 0.01$ & 43 & \\
\hline st16 & $34.8 \pm 1.0$ & $1.74 \pm 0.01$ & 64 & \\
\hline st17 & $32.6 \pm 0.9$ & $1.69 \pm 0.01$ & 96 & \\
\hline st18 & $44.0 \pm 0.9$ & $1.67 \pm 0.02$ & 62 & \multirow{5}{*}{ IV Hehuai Basin } \\
\hline st19 & $32.8 \pm 1.0$ & $1.65 \pm 0.01$ & 82 & \\
\hline st 20 & $28.8 \pm 1.5$ & $1.88 \pm 0.03$ & 118 & \\
\hline st21 & $30.2 \pm 0.8$ & $1.85 \pm 0.01$ & 81 & \\
\hline st 22 & $31.2 \pm 0.9$ & $1.70 \pm 0.01$ & 147 & \\
\hline
\end{tabular}

a) Station st09 has no well-recorded earthquake event; b) station st11 and st18 lie on the tectonic boundaries with complex crustal structure. The crustal thickness $(H)$ beneath them is large and unreasonable. So their results are not adopted in Figure 5.
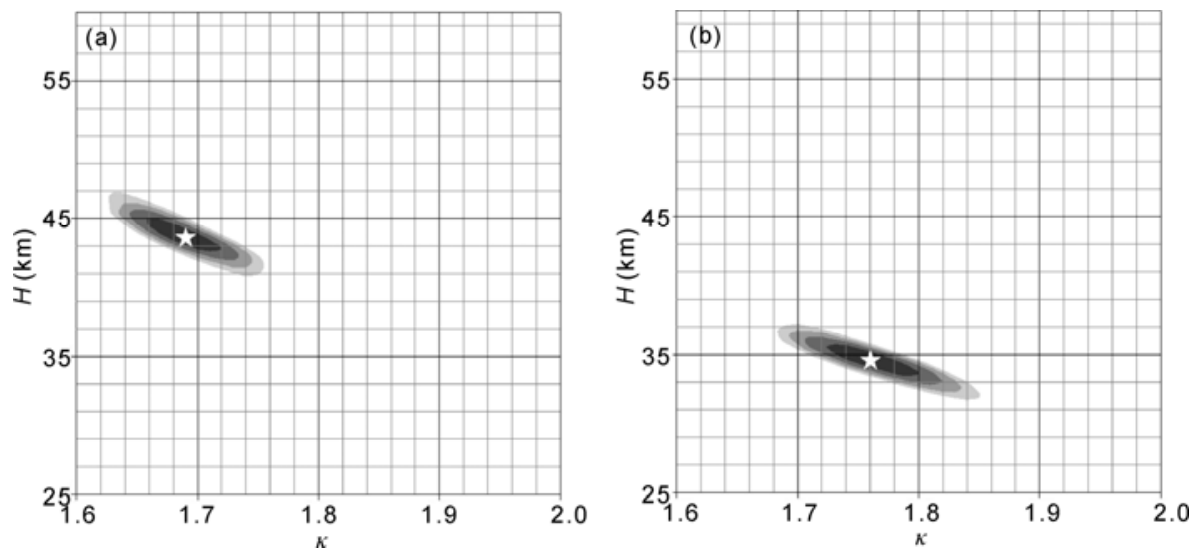

Figure 4 Two examples of the $H-\kappa$ stacking results obtained from Station st01 (a) and st14 (b) located in the Ordos Block and the Xionger-Funiu Mountains, respectively. Location of the amplitude peak is indicated by the white star.

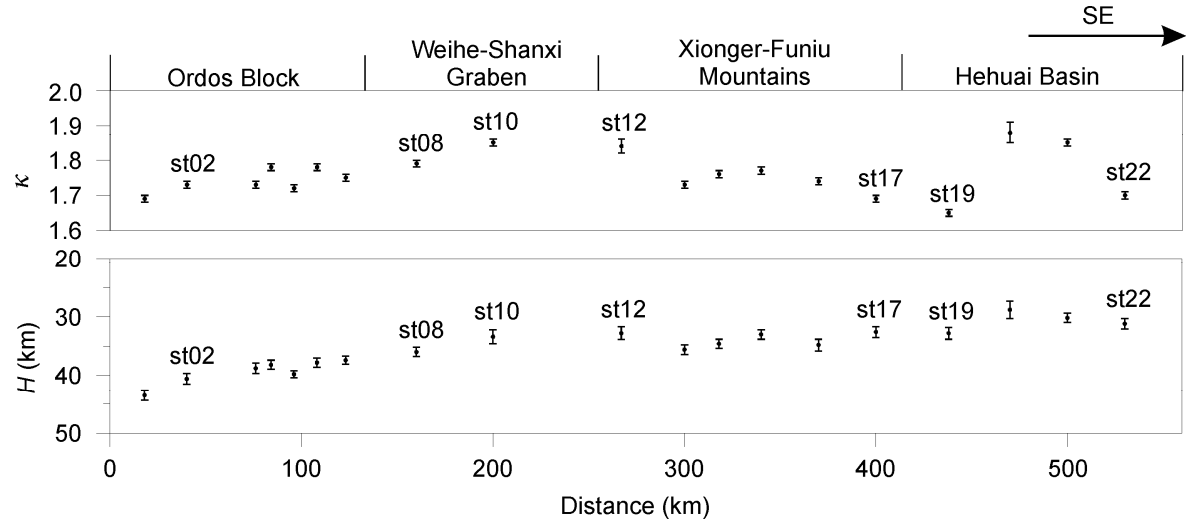

Figure 5 The depth and $\kappa$ section shows Moho depth and $V \mathrm{p} / V \mathrm{~s}$ ratio vary along the Profile $\mathrm{AB}$. 


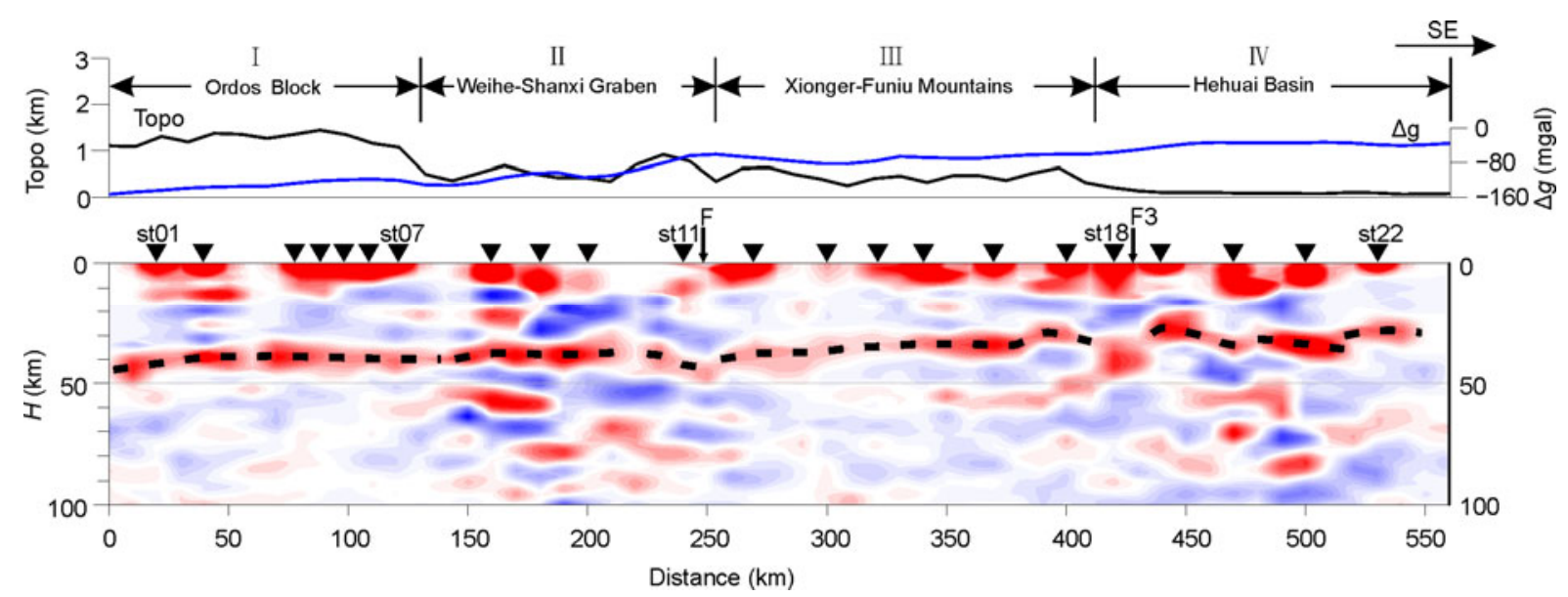

Figure 6 The CCP migration image of receiver functions along the Profile AB. The red represents positive stacking amplitude, and the blue represents negative stacking amplitude. The black triangles are stations' locations projected on to the Profile AB. The black dashed line marks the depth of the Moho. F and F3 denote faults (Figure 1(c)). Tectonic regions of the Profile AB are shown at the top. At the top, the black line is the surface topography and the blue line is the Bouguer gravity anomaly.

earthquakes have been rare and heat flow values are low [25]. This stable crustal structure indicates that the Ordos Block is a typical cratonic block.

The Moho beneath the Weihe-Shanxi Graben is observed to be uplifted by as much as $3 \mathrm{~km}$ relative to neighboring areas. Pan et al. [22] and Zhao et al. [23] obtained similar results in this area. Bouguer gravity anomalies support an upwarp in the graben (Figure 6) and heat flow values are relatively high [25]. The uplifted Moho may reflect the upwelling of upper mantle materials beneath the WeiheShanxi Graben. Tang et al. [26] obtained a similar result in the northern Shanxi Graben. However, their results show that the Moho has an upwarp of about 4 to $6 \mathrm{~km}$. So the upwelling of upper mantle materials may be stronger in the north than that in the south.

Near Station st11, the Moho is clearly interrupted. Bouguer gravity anomalies have a relatively big gradient near Station st11 (Figure 6). From Figure 1(c), we can see that Station st11 is located on the eastern extension of the Weihe Fault (F5) or the western extension of the southern marginal fault zone of the Taihangshan Mountains (F4). F4 is the boundary between the southern and northern NCB [27], and F5 may be the plate boundary between the Ordos Block and the Qinling Orogen [28]. Therefore, Station st11 may be located on a deep fault $(\mathrm{F})$, which even influences the lower crust.

The Moho becomes flat and continuous again at a depth between 36 and $33 \mathrm{~km}$ below the Xionger-Funiu Mountains in the southern NCB. The crustal structure in this area is stable. However, due to the N-S compression in the Triassic followed by extension, this region appears to have a tectonic framework of ridges and basins on the surface. Therefore, the stable crustal structure suggests that these tectonic activities did not influence the lower crustal structure in this area.

The flat and continuous features of the Moho terminate near Station st18. The Moho is again clearly interrupted beneath Station st18. Near Station st18, there is a fault named the Sanmenxia-Lushan Fault (F3) across the Profile AB. The results suggest F3 may be characterized by the deep fault. The aeromagnetic anomaly values are high to the north of F3 [29] and F3 is considered as the boundary between the stable and active areas of the southern NCB $[29,30]$.

Passing through the Sanmenxia-Lushan Fault, the Moho becomes uneven and complex at a depth of around $31 \mathrm{~km}$ in the southwestern Hehuai Basin, which is adjacent to the northern margin of the Qinling Orogen. The result reflects complex crustal structures and tectonic environments in this area. This area belongs to a tectonic active region in the southern NCB [29,30]. Since the SCB collided with the NCB in the Late Paleozoic, the tectonic evolution in this area has been continuously active. During the Cenozoic, many of the approximately E-W and WNW-ESE striking left-lateral strike-slip faults were formed due to the uplift and eastward extrusion of the Tibetan Plateau [5,6]. Therefore, the lower crust may also have been modified and superimposed during these periods of tectonic evolution, resulting in the development of a complex structure.

We thank the Seismological Bureau of Shanxi and Henan Provinces for their help during the field seismic experiments. We thank Huang $Z C$, Wang $P$, Mao X L and Xu $S B$ for help in this study. We also thank the reviewers for their helpful and reasonable advice. This work was supported by the National Natural Science Foundation of China (40634021).

1 Zhao G C, Wilde S A, Cawood P A, et al. Archean blocks and their boundaries in the North China Craton: Lithological, geochemical, structural and P-T path constraints and tectonic evolution. Precambrian Res, 2001, 107: 45-73

2 Wu F Y, Xu Y G, Gao S, et al. Lithospheric thinning and destruction of the North China Craton (in Chinese). Acta Petrol Sin, 2008, 24 : 1145-1174

$3 \mathrm{Xu} \mathrm{H} \mathrm{L,} \mathrm{Zhao} \mathrm{Z} \mathrm{J,} \mathrm{Lü} \mathrm{F} \mathrm{L,} \mathrm{et} \mathrm{al.} \mathrm{Tectonic} \mathrm{evolution} \mathrm{of} \mathrm{the} \mathrm{nanhuabei}$ area and analysis about its petroleum potential (in Chinese). Geotect Metal, 2004, 28: 450-463 
4 Qiu R Z, Deng J F, Zhou S, et al. Lithosphere types in North China: Evidence from geology and geophysics (in Chinese). Sci China Ser D-Earth Sci, 2004, 34: 698-711

5 Huang W, Wu Z W. Evolution of the Qinling orogenic belt. Tectonics, 1992, 11: 371-380

6 Zhang Y Q, Vergely P, Mercier J. Active faulting in and along the Qinling Range (China) inferred from SPOT imagery analysis and extrusion tectonics of south China. Tectonophysics, 1995, 243: 69-95

7 Zhu R X, Zheng T Y. Destruction geodynamics of the North China Craton and its Paleoproterozoic plate tectonics. Chinese Sci Bull, 2009, 54: 3354-3366

8 Zhao Z X, Xu J R. Three-dimensional crustal velocity structure of $\mathrm{P}$, wave in East China from wide-angle reflection and refraction surveys. Chinese Sci Bull, 2009, 54: 1389-1397

9 Jia S X, Zhang X K. Crustal structure and comparison of different tectonic blocks in North China (in Chinese). Chin J Geophys, 2005, 48: $611-620$

10 Zhao G Z, Zhan Y, Wang L F, et al. Electric structure of the crust beneath the Ordos fault block (in Chinese). Seismol Geol, 2010, 32: 345-359

11 Tian X B, Teng J W, Zhang H S, et al. Structure of crust and upper mantle beneath the Ordos Block and the Yinshan Mountains revealed by receiver function analysis. Phys Earth Planet Int, 2011, 184: 186193

12 Langston C A. Structure under Mount Rainier, Washington, inferred from teleseismic body waves. J Geophys Res, 1979, 84: 4749-4762

13 Xu Q, Zhao J M, Cui Z X, et al. Moho offset beneath the central Bangong,Nujiang suture of Tibetan Plateau. Chinese Sci Bull, doi: 10.1007/s11434-009-0387-9

14 Mi N, Wang L S, Li H, et al. Velocity structure of the crust and uppermost mantle in the boundary area of the Tianshan Mountains and the Tarim Basin. Chinese Sci Bull, 2005, 50: 270-275

15 Wu Q J, Tian X B, Zhang N L, et al. Receiver function estimated by maximum entropy deconvolution (in Chinese). Acta Seismol Sin, 2003, 25: 382-389

16 Schimmel M, Paulssen H. Noise reduction and detection of weak, coherent signals through phase,weighted stacks. Geophys J Int, 1997, 130: 497-505

17 Yuan X H, Ni J, Kind R, et al. Lithospheric and upper mantle structure of southern Tibet from a seismologiacl passive source experi- ment. J Geophys Res, 1997, 102: 27491-27500

18 Zhu L P, Kanamori H. Moho depth variation in southern California from teleseismic receiver functions. J Geophys Res, 2000, 105: 29692980

19 Dueker K G, Sheehan A F. Mantle discontinuity structure from midpoint stacks of converted $\mathrm{P}$ to $\mathrm{S}$ waves across the Yellowstone hotspot track. J Geophys Res, 1997, 102: 8313-8327

20 Kind R, Yuan X H, Saul J, et al. Seismic images of crust and upper mantle beneath Tibet: Evidence for Eurasian Plate subduction. Science, 2002, 298: 1218-1221

21 Yuan X H, Sobolev S V, Kind R, et al. Subduction and collision processes in the Central Andes constrained by converted seismic phases. Nature, 2000, 408: 958-961

22 Pan S, Niu F. Large contrasts in crustal structure and composition between the Ordos plateau and the NE Tibetan plateau from receiver function analysis. Earth Planet Sci Lett, 2011, doi: 10.1016/j.epsl. 2011.01.007

23 Zhao J R, Zhang X K, Wang F Y, et al. North China sub,craton lithospheric structure elucidated through coal mine blasting. Chinese Sci Bull, 2009, 54: 669-676

24 Jiang W W, Hao T Y, Song H B. Crustal structure and geological and geophysical features of Ordos basin (in Chinese). Prog Geophys, 2000, 15: 45-53

25 Hu S B, He L J, Wang J Y. Heat flow in the continental area of China: A new data set. Earth and Planet Sci Lett, 2000, 179: 407-419

26 Tang Y C, Feng Y G, Chen Y S, et al. Receiver function analysis at Shanxi rift (in Chinese). Chin J Geophys, 2010, 53: 2102-2109

27 Zhang Y Q, Ma Y S, Yang N. Neotectonic activity of the southern marginal fault zone of the Taihangshan Mountains and its regional kinematic implications (in Chinese). Seismol Geol, 2003, 25: 169182

28 Huang $\mathrm{Z} \mathrm{C}, \mathrm{Xu} \mathrm{M} \mathrm{J}$, Wang L S, et al. Shear wave splitting in the southern margin of the Ordos Block, North China. Geophys Res Lett, 2008, 35: L19301, doi:10.1029/2008GL035188

29 Yang M H, Wang S M, Zheng X F, et al. Aeromagnetic anomalies characteristics and tectonic subareas of southern North China Craton and adjacent regions(in Chinese). Geol Rev, 2009, 55: 862-872

$30 \mathrm{Xu} \mathrm{H} \mathrm{L,} \mathrm{Zhao} \mathrm{Z} \mathrm{J,} \mathrm{Yang} \mathrm{Y} \mathrm{N,} \mathrm{et} \mathrm{al.} \mathrm{Structural} \mathrm{pattern} \mathrm{and} \mathrm{structural}$ style of the Southern North China Basin (in Chinese). Acta Geosci Sin, 2003, 24: 27-33

Open Access This article is distributed under the terms of the Creative Commons Attribution License which permits any use, distribution, and reproduction in any medium, provided the original author(s) and source are credited. 